\title{
Risk Mitigation Strategies in Public Procurement Process:
}

\author{
Evidence from Sukabumi City, Indonesia
}

\author{
Septiana Dwi Putrianti* \\ Postgraduate Program \\ Polytechnic STIA LAN Bandung \\ Bandung, Indonesia \\ *septiana.dwiputrianti@poltek.stialanbandung.ac.id
}

\author{
Ibnu Munggara Amrullah \\ Civil Service of Sukabumi City Government \\ Sukabumi, Indonesia \\ munggaraibnu@yahoo.co.id
}

\begin{abstract}
This article addresses risks in implementing public procurement policy in Sukabumi City. This study aims to gain further understanding of the implementation of policies, internal and external factors that analyze to create strategies to mitigate the risks in implementing public procurement policy. This research provides data and evidence on why implementation of government procurement policy is not able to be effective. The qualitative, SWOT analysis method and a litmus test are employed to explicate phenomena during the implementation of public procurement policy at Sukabumi City. Within each dimension of policy implementation, there are multiple weaknesses, including lack of communication between stakeholders, less understanding of the public procurement's regulations, lack of quality and quantity in human resources, a strong negative intervention that influencing disposition/character of procurement actors, and bureaucratic structure that has not supported in implementation. a litmus test is used to identify strategic issues. The strategy enables to mitigate administrative risks within the process of implementation of public procurement policy in Sukabumi City. Strategies can be manifested by developing procurement apps, namely: SiCamperenik; adding tender schedule and alarm to the application to ensure the tender process can be done timely; creating a roadshow program to increase the competences of procurement actors; producing guideline book regarding risks mitigation as a technical guide for public procurement actors; creating procurement local catalog to enhance role and participation of local entrepreneur; initiating commitment with civil services to create the functional position of public procurement, and creating independent Electronic Procurement Service (LPSE).
\end{abstract}

Keywords-policy implementation, risk mitigation, procurement, SWOT analysis, strategic management

\section{INTRODUCTION}

Strategic issues related to the facilitation of government public procurement services are the rise of failed work/budget is not absorbed, lawsuits, state financial losses due to factors such as unpreparedness of personnel appointed as procurement actors, the existence of outside intervention, administrative negligence, deliberate rule deviations, and the unmissable information about what will happen. Something uncertain can have beneficial or detrimental consequences. Risk is an expression of the likelihood and impact of the uncertainty of an event, which is sudden and extreme, and if it occurs, has the possibility of having a positive or negative impact on the achievement of a project or program objective. The number of parties involved and interested in the public procurement of government starting from the stages of planning, selection of business actors, and post-election involve various parties following their competence. There are differences in perception in understanding Presidential Regulation No. 16 of 2018 into gaps and opportunities for problems that if not managed or mitigated can cause new problems and even result in complex legal processes.

Sukabumi City is not separated from the risks, several tender packages are not absorbed / not carried out development. Based on tender data in 2019 there are fifty-two tender packages where fourteen packages are not absorbed. The dominant risks occurring in Sukabumi city are administrative risks, including low levels of compliance, administrative negligence, and completeness of documents that have an impact on delays in implementation, losses, unabated budgets, and even legal aspects such as lawsuits.

Based on previous research related to the implementation of public procurement policy in regional devices, namely research from Syarifuddin [1], research using Edward III theory on (Provincial Government "ST") and research from Azzahroh [2] related to risk management strategy in the private sector. The research used SWOT analysts to formulate a strategy on (City "B" investment). Several efforts have been made to address the problem. Based on the explanation above, this study aims to analyze the Implementation of government public procurement policy using Edward III theory, and SWOT analysis to identify strategic issues in formulating risk mitigation strategies in the public procurement process in Sukabumi City. 


\section{THEORY REVIEW}

\section{A. Public Procurement Theory}

Sutedi [3] states that public awareness is essentially an effort by the user to obtain or realize the desired goods and services, using certain methods and processes to reach a price agreement, time, and other agreements. Public procurement of government is one of the supporting elements in the development of a country in supporting the wheels of the economy and services to the community

\section{B. Public Policy Implementation Theory}

Implementation of public policy will be easier to understand when using a particular model or frame of mind. Edward III [4] asserted that the main problem of public administration is lack of attention to implementation, furthermore, Edward III said that the success of policy implementation is influenced by four factors namely communication, resources, disposition, and bureaucratic structure.

\section{Strategy Theory}

The strategy is important for the survival of an organization to achieve effective and efficient goals or objectives, the organization must be able to face any problems or obstacles that come from within or from outside the organization. David [5] defines "strategy is a common means with long-term goals to be achieved.

\section{SWOT Analysis}

According to Rangkuti [6] SWOT analysis is a way to systematically identify various factors to formulate the company's strategy. This analysis is based on the logic that can maximize strengths and opportunities but can simultaneously minimize weaknesses and threats. SWOT analysis considers the external environmental factors of opportunities and threats facing the business world as well as the internal environment of strengths and weaknesses. SWOT analysis compares external factors of opportunity and threat with internal factors of strengths and weaknesses so that from such analysis can be taken a strategic decision of an organization.

\section{RESEARCH METHODS}

This research uses the qualitative research method, which is scientific research, which aims to understand a phenomenon in a social context naturally by prioritizing the process of deep communication interaction between researchers and phenomena in a natural social context by prioritizing the process of deep communication interaction between researchers and the phenomenon studied [7].

The focus of this research is to determine the risks in the implementation of government public procurement policy reviewed with Edward III theory, then analyze internal and external environmental factors by weighting and assessment through focus group discussion mechanism to avoid the subjectivity of research that is continued by SWOT matrix, strategy quadrant analysis and litmus test to formulate risk mitigation strategy in the public procurement process in Sukabumi City.

Data collection techniques used include interviews, observations, and documentation studies. Data analysis techniques used are internal matrix analysis (IFAS) and external matrix (EFAS), Internal-External matrix (IE) to determine cell position and general strategy which is then combined into SWOT matrix analysis to provide alternative strategies. Strategic issues are carried out litmus tests based on theory [8] obtained through the focus group discussion mechanism to find out the most priority strategic issues.

\section{DISCUSSION}

The research location of Sukabumi City Public Procurement Agency, located in Sukabumi City Hall. This study found as following:

\section{A. Policy Implementation}

Based on the results of interviews, observations and documentation studies to analyze the implementation of public procurement policy in Sukabumi city according to Edward III theory obtained information that the implementation is still not optimal, there are still weaknesses in each dimension, namely:

1) Communication: The success of the policy requires implementors to know what to do. What are the objectives and objectives of the policy? If the objectives and objectives of a policy are unclear or even unknown to the target group, then there is likely to be resistance from the target group. The delivery of information through socialization activities has not provided the same understanding and not all policy implementers receive the latest policy information, the implementation of unscheduled tenders, unscheduled so that it accumulates in the second half and many late tender packages;

2) Resources: These resources can take the form of human resources, namely implementor competitions and financial resources, infrastructure, and authority. Resources are an important factor for policy implementation to be effective. Without resources, the policy of just staying on paper becomes a document only. Based on the results of interviews and observations, it can be known that the number of Electoral Pokja is limited, the commitment-making officials have not been competent because most of the positions are appointed because the positions attached to the institutional organization are not because they have a certificate of expertise, Sukabumi city does not have its electronic procurement service system.

3) Disposition/Character: Disposition is the character and characteristics or attitudes possessed by implementors such as commitment, honesty, democratic nature. If the implementor has a good disposition, then he/she will be able to carry out the policy as well as what the policymaker wants, from the results of interviews and observations obtained information that in the 
process of public procurement there is negative political intervention and mental unpreparedness of appointed officials in the Procurement Organization becomes an obstacle in the implementation of the policy;

4) Bureaucratic structure: Bureaucratic structure in charge of implementing policies has a significant influence on policy implementation, based on the results of interviews and observations obtained information that selection status is not functional, currently, BPBJ Sukabumi city is at the level of 2 of 5 levels of institutional maturity, one of the instruments that have not been met is the absence of functional power Pokja Pemilihan and does not have its electronic procurement service system.

\section{B. Strategic Internal and External Environmental Factors}

1) Analysis of strategic factors of the internal environment in the public procurement process: Nawawi [9] stated that the internal conditions that need to be analyzed are human resources conditions in terms of quality and quantity, technology including facilities and infrastructure, available budgeting systems, supporting internal regulations, attitudes, and commitments of top management.

Based on the observations through interviews and observations attributed to the findings in the implementation of policies according to Edward III can be described that the strengths factors are the Public Procurement Agency already has a Mayor's Regulation on the code of conduct of public procurement personnel, has a SiCamperenik application that facilitates the administration of tenders, has an adequate budget, has a consultancy clinic program to improve the competence of procurement actors, and has a respected leadership because it doubles as a national trainer and expert witness KPK while the factor of weakness is The quantity of Pokja Pemilihan is very lacking, lack of competence of Commitment Making Officer, lack of procurement functional personnel, do not have their electronic procurement service system, and lack of motivation of Commitment Making Officer because the allowance is not proportional to the risk of employment.

2) Analysis of external environmental strategic factors in the public procurement process: Tangkilisan [9] stated that in reviewing the opportunities and threats of an external dimension must be returned to its influence on the achievement of goals. If external factors support internal factors then that is an opportunity. Conversely, if external factors inhibit internal factors is a threat to the organization.

Based on the observations through interviews and observations attributed to the findings in the implementation of the policy according to Edward III can be described that the opportunity is an agreement with the Regional Staffing Agency that participants who pass the public procurement exam will be made an Election Working Group, there is a policy from the Public Procurement Policy Institute that the electoral working group must already be a functional employee no later than 2021, the Budget of the Public Procurement Agency supports the implementation of policies, the monitoring, and evaluation of the companion/facilitator and the existence of a program to increase the competence of the Public Procurement Policy Institute to be an opportunity to improve the competence of Commitment Making Officers and Election Working Groups. While the threat is a negative political intervention, many outside parties are interested and there is the interference of thugs, the ability of local businesses is less competitive, the policies used are not in sync with other policies used examples of rules in the Presidential Regulation and Regulation of the Minister of Public Works for construction work and force majeure such as natural disasters, fires, covid-19.

Based on Focus Group Discussion results that internal and external environmental analysis obtained total weight calculation score and rating i.e. strength: 3.91, weakness score: 2.11, odds score 3.29 , and threat score 1.94 .

3) SWOT analysis: Influential issues in the internal and external environments are created SWOT matrix by combining internal and external environments to obtain strategic issues. SWOT Matrix, Merging Internal and External Factors influencing the Public Procurement Process.

Quadrant analysis of the strategy to confirm the axis position between strengths and weaknesses, as well as opportunities and threats are all described in positive and negative lines (Figure 1). The determination of coordinates for SWOT analysis is obtained based on calculations (strength score -weakness score);(scoring odds - threat score) with the result coordinates located at $(0,9 ; 0.675)$

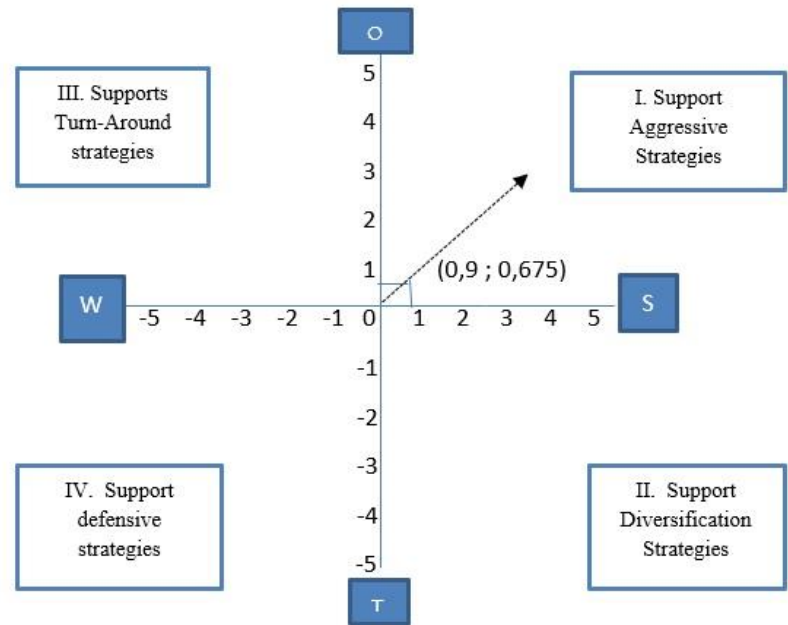

Fig. 1. SWOT analysis position results of public procurement process in Sukabumi City.

Based on the analysis placed in the position of quadrant one means the organization has enough opportunities and strength to optimize the potential that exists to utilize existing power to solve the problem (Figure 2). 
TABLE I. SWOT MATRIC FACTORS INFLUENCING THE PUbLIC PROCUREMENT PRocess

\begin{tabular}{|c|c|}
\hline Strategy (SO) & Strategy (WO) \\
\hline $\begin{array}{l}\text { - Develop applications with the addition of scheduled plan features } \\
\text { with alarms. Application development to tender on time. } \\
\text { - Create a roadshow program for regional devices to improve the } \\
\text { competence of Procurement Actors in each Government office. } \\
\text { - Make a risk mitigation handbook in public procurement to become a } \\
\text { guideline for procurement actors as a preventive effort. } \\
\text { - Create regional catalogs to increase the participation of local } \\
\text { entrepreneurs. } \\
\text { - Coordinate with the Regional Staffing Agency to functionalize the } \\
\text { existing Election Working Group and make an agreement that } \\
\text { participants who pass the Public Procurement Training are willing to } \\
\text { become Functional employees }\end{array}$ & $\begin{array}{l}\text { - Intervene in the Regional Personnel Agency to often conduct public } \\
\text { procurement training to multiply procurement experts to become } \\
\text { procurement actors in their agencies. } \\
\text { - Create an independent electronic procurement service system. } \\
\text { - Create technical guidance or training activities organized by public } \\
\text { procurement policy institutions or other institutions to improve the } \\
\text { competence of Commitment Making Officers (certified) } \\
\text { - Make a forecast schedule for the reference Commitment Making } \\
\text { Officer carry out the tender (copy to the Mayor, Prosecutor, Tipikor). } \\
\text { - Advocacy efforts for the appointed Commitment Making Officer be } \\
\text { under his or her area of expertise, such as construction tenders by a } \\
\text { Commitment Making Officer with a background in civil engineering } \\
\text { education }\end{array}$ \\
\hline Strategy (ST) & Strategy (WT) \\
\hline $\begin{array}{l}\text { - Maximizing the review of the determination of the Commitment } \\
\text { Making Officer, is to avoid discriminatory requirements and other } \\
\text { requirements that are not normative. } \\
\text { - Forcing Regional Devices to prioritize tenders sourced from Special } \\
\text { Allocation Fund funds to be implemented at the beginning of the year. } \\
\text { - Conduct technical guidance of business actors to improve competence } \\
\text { in the implementation of tenders normatively. } \\
\text { - Synergize with the legal department and inspectorate related to legal } \\
\text { aid if there is a complaint /complaint/reporting. } \\
\text { - Maximizing the role of prosecutors and corruption team and } \\
\text { monitoring for evaluation of the implementation of tenders at every } \\
\text { stage }\end{array}$ & $\begin{array}{l}\text { - Maximizing the role of the regional prosecutor and the Police Tipikor. } \\
\text { - Organizing routine competency improvement activities for } \\
\text { commitment Making Officers at the Public Procurement Policy } \\
\text { Institute } \\
\text { - Personnel of Public Procurement Institutions Conduct assistance to } \\
\text { Regional Devices in the tender planning process } \\
\text { - Make advocacy efforts to improve the income welfare of the } \\
\text { Commitment Making Officer } \\
\text { - Appeal to all Electoral Working Parties and procurement actors in the } \\
\text { Procurement Organization on Regional Devices to make and sign } \\
\text { integrity facts }\end{array}$ \\
\hline
\end{tabular}

4) Litmus test: To address strategic issues that are a priority, a litmus test is carried out using the Tangkilisan model [9] where there is an instrument that determines the score of the strategic issue, the higher the score, the higher the priority of the issue. Based on Focus Group Discussion of twenty issues strategies six strategies obtain high scores so that it is determined as a priority strategy.

5) Risk mitigation strategy in public procurement process: The strategy recommended by researchers based on quadrant analysis of strategy and litmus test is expected to help Sukabumi City to mitigate risks in the public procurement process. Researchers recommend six alternative strategies including developing applications with the addition of scheduled plan features in order to tender on time, this is related to addressing problems from the communication aspect to make the tender more scheduled and from the aspect of disposition / disposition so that procurement actors who usually delay the submission of tenders piled up in the second half then with the development of this application will be forced to be on schedule, Creating a roadshow program to Regional Devices to improve the competence of procurement actors in each government units, this is to overcome the problem of communication aspects so that policies can be conveyed and to improve competence with the target of all personnel in each Regional Device, as well as to accommodate and overcome problems in the implementation of policies in regional devices, Make a guidebook mapping risks in public procurement at every stage to become guidelines for procurement actors as a preventive effort, this is to overcome the problems of communication aspects and disposition / character wherewith this handbook, procurement actors can know the potential risks and impacts that will be received. In addition to providing understanding, this will also change the habits of procurement actors to be more normative according to the rules, Creating regional catalogs to increase the participation of local entrepreneurs, this is to overcome the problems of the resource aspects of pre-existing facilities that support the implementation of policies, Make agreements with the Regional Staffing Agency to functionalize the existing Election Working Group and make an agreement that participants who pass the public procurement training are willing to become functional workers pokja elections, this is to overcome the problems of the human resources aspect related to the lack of number of Election Pokja and aspects of bureaucratic structure because of the current Public Procurement Agency Sukabumi city is on the level of two of the five levels of institutional maturity, where one of the instruments that have not been met is the absence of functional power Pokja Pemilihan, Making Electronic Procurement Services itself to improve services, especially to local businesses, this is to overcome the problem of the aspects of infrastructure related resources and aspects of bureaucratic structure in the fulfillment of institutional maturity level, where one of the instruments that has not been met is not yet have its own Electronic Procurement Service. 


\section{CONCLUSION}

Risks in the public procurement process in Sukabumi city occurred due to the implementation of policies that have not been optimal both in terms of communication, resources, disposition, and bureaucratic structure. Research produces proposed strategies to mitigate risks in public procurement. For the proposed strategy to work, coordination between the relevant parties is required, identifying the needs, and planning for its budgeting.

\section{REFERENCES}

[1] S. Syarifuddin, "Implementasi Kebijakan Pengadaan Barang Dan Jasa E-procurement Pada Dinas Cipta Karya, Perumahan Dan Tata Ruang Daerah Provinsi Sulawesi Tengah,” Katalogis, vol. 3, no. 11, 2019.
[2] A. Azzahroh, Strategi Manajemen Risiko PT BPRS. Skripsi. Bekasi: UIN Syarif Hidayatullah, 2013.

[3] A. Sutedi, Aspek Hukum Pengadaan Barang dan Jasa dan Berbagai Permasalahannya. Jakarta: Bumi Aksara, 2012.

[4] G.C. Edward III, Implementing Public Policy.Washington DC: Congressional Quarterly Press, 1980.

[5] F.R. David, Strategic Management, Jakarta: Book 1. Edition 12, 2011.

[6] F. Rangkuti, Analisis SWOT: Teknik Membedah Kasus Bisnis. Jakarta: PT. Gramedia Pustaka Utama, 2014

[7] H. Herdiansyah, Metode Penelitian Kualitatif untuk Ilmu-ilmu Sosial. Jakarta: Salemba Humanika, 2010.

[8] H.N.S. Tangkilisan, Implementasi Kebijakan Publik Transformasi Pikiran George Edwards. Yogyakarta: Lukman Offset, 2003.

[9] H. Nawawi, Manajemen Strategik, Yogyakarta: Gajah Mada University Press, 2005. 